14. Markarian J. Blow-fill-seal Technology Advances in Aseptic Filling Applications. New advanced aseptic manufacturing technologies are available for filling liquid pharmaceuticals, including biologics // Equipment and Processing Report. 2014. URL: http://www.pharmtech.com/blow-fill-seal-technology-advances-aseptic-filling-applications

15. Simmchen J., Ventura R., Segura J. Progress in the Removal of Di-[2-Ethylhexyl]-Phthalate as Plasticizer in Blood Bags // Transfusion Medicine Reviews. 2012. Vol. 26, Issue 1. P. 27-37. doi: 10.1016/j.tmrv.2011.06.001

16. Polova Z., Almakayeva L., Nehoda T. Development of the composition of intramammary combined preparation based on silver citrate for veterinary // Ceska a Slovenska Farmacie. 2017. Issue 66 (5). P. 227-233.

17. Polova Zh. N., Almakaeva L. G. Issledovanie stabil'nosti obrazcov protivomastitnogo preparata «Argocid» // Respublikanskiy nauchnyy zhurnal «VESTNIK» Yuzhno-Kazahstanskoy gosudarstvennoy farmacevticheskoy akademii. 2017. Issue 4 (81). P. 154-159.

18. Sayt TzOV «Brovafarma». URL: http://brovafarma.com.ua/uk/news/evropejs-ki-tehnologii-virobnictva-za-gmp.html

19. Derzhavna farmakopeia Ukrainy. Vol. 1. 2-e vyd. Kharkiv: Derzhavne pidpryiemstvo «Ukrainskyi naukovyi ekspertnyi farmakopeinyi tsentr yakosti likarskykh zasobiv», 2015. $1128 \mathrm{p}$.

Дата надходження рукопису 16.01.2018

Zhanna Polova, PhD, association of professor, Department of pharmaceutical and industrial technology of medicines, O. O. Bogomolets National Medical University, T. Shevchenko blvd., 13, Kyiv, Ukraine, 01601 E-mail: zpolova@ukr.net

Lyudmyla Almakayeva, Doctor of Pharmaceutical Sciences, Professor, Head of laboratory, Laboratory of parenteral and oral liquid medicines , National University of Pharmacy, Pushkinska str., 53, Kharkiv, Ukraine, 61002

UDC 582.282.23:57.017.4:615.282:618.15-002.828

DOI: 10.15587/2519-4852.2018.124534

\title{
IN VITRO SUSCEPTIBILITY STUDY OF CANDIDA SPP. ISOLATES TO NEW COMBINED POTENTIAL MEDICINAL PRODUCT FOR THE TREATMENT OF VAGINAL CANDIDIASIS
}

\section{(C) I. Nizhenkovska, L. Zinchenko}

Дослідження протимікробної дї модельних зразків потенційного лікарського засобу у різних фіксованих комбінаціях та доведення специфічної антимікотичної активності модельних зразків нового, комбінованого, потениійного лікарського засобу та препарату, обраного в якості референтного «НеоПенотран $^{\circledR} \gg($ Екселтіс Хелске С.Л., Іспанія).

Метою дослідження було встановлення чутливості in vitro ізолятів Candida spp. до нового комбінованого лікарського засобу, що містить в своєму складі субстанцію з антимікотичною дією для лікування вагінального кандидозу.

Матеріали та методи. Для доведення активності та визначення чутливості використовували ізоляти Candida albicans (ATCC 10231) ma Candida albicans (клінічний ізолят) з матеріалу, урогенітальних шляхів від жінок з діагнозом кандидоз.

Вивчення протимікробної дї проводили за методом серійних розведень в триптиказо-соєвому бульйоні, щзо дозволив забезпечити рівномірний розподіл препарату в поживному середовищі при контакті з патогенними штамами, а подальший пересів на чашки Петрі на Сабуро агар - найбільш точну оцінку результатів.

Результати вивчення антимікотичної активності 7 модельних зразків, свідчать про наявність антимікотичної активності лише у 3 модельних зразках по відношенню як до еталонного штаму Candida albicans ATCC 10231, так і клінічного штаму Candida albicans.

Висновки. Отримані результати досліджень свідчать про наявність виразного антимікотичного ефекту in vitro нового потенційного комбінованого лікарського засобу відносно патогенних тест-цтамів: Candida albicans ATCC 10231, Candida albicans (клінічний ізолят), який не поступається обраному референтному препарату. Встановлено мінімільну інгібуючу кониентрацію досліджуваного препарату іп vitro відносно патогенних тест-итамів: Candida albicans ATCC 10231, Candida albicans (клінічний ізолят). Проведене дослідження різних комбінаџій та кониентрацій комбінованого препарату дозволило виключити наявність негативної взаємодії між компонентами експериментального зразку та виділити найбільш перспективний та ефективний зразок для подальших експериментальних досліджень комбінацій антимікотиків для інтравагінального застосування

Ключові слова: супозиторії, вагінальний кандидоз, антимікозна активність 


\section{Introduction}

Diseases with infectious etiology of the reproductive system of a woman are one of the most important medical and social problems in the structure of which the defeat of fungal nature play an essential role. However, there is practically no statistically reliable information on the prevalence of vaginal candidiasis (VC), since in most cases the disease is not isolated from other dysbiotic processes that are often recorded in women's vaginal biotope. The frequency of $\mathrm{VC}$ in the last five years has increased by 2 times and ranged from 26 to $45 \%$ in the structure of the infectious pathology of the gynecological profile [1].

2. Formulation of the problem in a general way, the relevance of the theme and its connection with important scientific and practical issues

Inflammatory diseases of the pelvic organs occupy one of the leading places in the structure of gynecological pathology and are detected in $60-65 \%$ of all gynecological patients. Inadequate treatment of these diseases leads to a chronic process, forming the basis of pathological conditions, which subsequently violate the fertile function of women.

To date, gynecological practice has widely used vaginal suppositories containing various active pharmaceutical ingredients (APIs). The range of multicomponent suppositories is only $11 \%$ of the total number of vaginal suppositories registered in Ukraine. Based on the foregoing, it can be argued that the importance of creating a vaginal suppository of multi-directional action for the treatment of VC.

3. Analysis of recent studies and publications in which a solution of the problem are described and to which the author refers

The main agents of these infections are fungi of the Candida genus [2]. The prevalence of Candida albicans in females of reproductive age is $83.7-86 \%$, nonalbicans species $-14-16.3 \%$ without a marked tendency to increase or decrease [3]. Often, vaginitis occurs due to the combination of several factors, for example, bacterial and fungal nature, accounting for 10 to $30 \%$ of all cases of infectious diseases in gynecology. The result of the mutual influence of pathogens is difficult to predict, but in most cases, the clinical picture is changing, which complicates the diagnosis and choice of adequate therapy [4]. In addition, to date no clear guidelines that allow evaluating the role allocated from the vaginal contents of fungi of the Candida genus, colonization of mucous membranes which in healthy people varies from 15 to $40 \%$ and may increase to $80 \%$ against the pathological process in prolonged hospitalization [5]. Being present in biocenosis, they interact with other types of conditionally pathogenic microorganisms and representatives of normal flora, changing the factors of persistence and virulence of the latter [6].

In microbial associations between different types of pathogens appear ambiguous relationship that could materially affect the nature of the infection [7], and requires the appointment of drugs that would have a complex pharmacotherapeutic activity.
4. The field of research considering the general problem, which is described in the article

Among the drugs for the treatment of candidiasis vulvovaginitis the most commonly used derivatives of azoles - metronidazole, tinidazole, clotrimazole, ketoconazole, miconazole and others. Compared with known antibiotics (nystatin, amphotericin, natamycin, etc.), these drugs provide more reliable and safer treatment for women with inflammatory lesions caused by fungal, protozoal and other infections [11]. Therefore, one of the components of the combined drug were selected imidazoles (metronidazole and clotrimazole), which until now remain the drugs of the first line of treatment of $\mathrm{VC}$ complicated by bacterial infection.

High permeability of active substances to the inaccessible excretory ducts of the glands, as well as crypt, lacunae with inflammation, along with the ease of administration without the help of medical personnel, indicate the promise of the investigated potential medicines in the form of suppositories.

\section{Formulation of goals (tasks) of article}

Aim of the research - to establish the sensitivity of in vitro Candida spp. isolates to a new combined drug containing a substance with an antimycotic effect for the treatment of vaginal candidiasis.

6. Presentation of the main research material (methods and objects) with the justification of the results

Materials and methods. Experimental studies were conducted in accordance with "Methodological recommendations for the preclinical study of potential drugs with antimicrobial activity" $[8,9]$ and the methodological recommendations "Determination of microorganism sensitivity to antibacterial preparations", approved by the Order of the Ministry of Health of Ukraine dated April 5, 2007, No. 167.

Candida albicans (ATCC 10231) derived from the UCM (Ukrainian Collection of Microorganisms, Institute of Microbiology and Virology of the National Academy of Sciences of Ukraine) and Candida albicans (clinical isolate) from the material, urogenital tracts from women with a diagnosis of candidiasis obtained in Institute of urology, NAMS of Ukraine.

Identification of Candida species was performed by investigating the structure of colonies in a chromogenic medium (ChromID TM Candida, Biomere, France) after 24-48 hours of incubation at $35^{\circ} \mathrm{C}$ using a standard system (API® Candida, Biomerej, France). To ensure purity and viability, frozen cells of yeast isolates were sown on Saburi agar with dextrose, chloramphenicol and incubated at $35{ }^{\circ} \mathrm{C}$ for 24 hours. This procedure was repeated twice before testing for sensitivity to the investigated pharmacological agents.

The study of antimicrobial activity was carried out by the method of serial dilutions in trypticase-soybean broth. The chosen approach allows ensuring the uniform distribution of the drug in the nutrient medium in contact with pathogenic strains, and the subsequent transfer to Petri dishes on Sabouraud agar - the most accurate evaluation of the results. 
The study of the antimicrobial effect of model specimens of a potential drug in various fixed combinations and the demonstration of specific antimycotic activity was performed using model samples of a new, combined, potential drug and drug selected as a reference "Neo-Penotran ${ }^{\circledR} "$ (Exeltis Healthcare S.L., Spain) (Table 1).

Table 1

Composition of the studied samples of medicinal products

\begin{tabular}{|c|l|c|}
\hline $\begin{array}{c}\text { Sample } \\
\text { No. }\end{array}$ & Composition (API) & $\begin{array}{c}\text { AFI content in g } \\
\text { per 1 suppository }\end{array}$ \\
\hline 1 & $\begin{array}{l}\text { Base + auxiliary } \\
\text { substances }\end{array}$ & up to 4.00 \\
\hline 2. & Ibuprofen & 0.08 \\
\hline 3. & Metronidazole & 0.10 \\
\hline 4. & Clotrimazole & 0.40 \\
\hline \multirow{2}{*}{5.} & Ibuprofen & 0.08 \\
\hline \multirow{2}{*}{6.} & Metronidazole & 0.10 \\
\hline \multirow{2}{*}{7.} & Ibuprofen & 0.08 \\
& Clotrimazole & 0.40 \\
\hline \multirow{2}{*}{8.} & Clotrimazole & 0.08 \\
& Metronidazole & 0.40 \\
& Neo-Penotran ${ }^{\circledR}$ & 0.10 \\
\hline
\end{tabular}

The studies began with the receipt of Candida albicans daily cultures, preparation of the initial and working suspensions of Candida albicans, and the aliquots hanging from the experimental and control suspensions to determine the minimum fungicidal concentrations (MFCs) of the preparations were carried out on a semiconductive medium of trypticase-soybean broth (TSB) in a test tube. Subsequently, he was transferred to Petri dishes with a solid nutrient medium - Sabouraud agar.

Parallel preparation of the initial solutions of model specimens of the new combined drug and the reference preparation Neo-Penotran ${ }^{\circledR}$ (Exeltis Healthcare S.L., Spain), obtained by melting the suppository in a water bath with the addition of $40 \mathrm{ml}$ of TSB medium. The initial concentration thus obtained was $1 / 4$ suppository in $10 \mathrm{ml}$ medium, which is $10 \mathrm{mg} / \mathrm{ml}$ clotrimazole. For further studies, the concentration of drugs in the initial solution was reduced by half compared with the previous one, namely: 1/8, 1/16, 1/32, $1 / 64,1 / 128$ and $1 / 256$ suppository corresponding to the concentration of $5,2,5,1.25,0.63,0.315,0.16,0.08$, $0.04 \mathrm{mg} / \mathrm{ml}$ of clotrimazole, respectively. For this purpose, $5 \mathrm{ml}$ of the initial solutions were mixed with a similar volume of the TBC nutrient medium. A similar way was achieved by doubling the concentrations of the initial solutions for the study of activity against Candida albicans. Subsequently, for each type of Candida spp., a number of $8-10$ samples were prepared, in which the appropriate test was carried out, strains of microorganisms of $0.1 \mathrm{ml}$. Concentration of culture in test tubes with drugs and control of culture was about $5 \times 10^{6}$ in $1 \mathrm{ml}$.

The inoculations were incubated for 2 days at $37.5{ }^{\circ} \mathrm{C}$. After the incubation was complete, from each test tube, a loop was driven onto cubes with Sabouraud agar medium on a solid nutrient medium. Cultures were incubated for 2 days at $37.5^{\circ} \mathrm{C}$. In this case, the titers of Candida albicans strains were $5 \times 10^{7} \mathrm{CFU}$ in $0.1 \mathrm{ml}$, which corresponded to the requirements of the experiment in accordance with similar studies.

In experimental samples, working concentrations, from which the study of the effect of a new combined drug with antimycotic and anti-inflammatory activity on test microorganisms, was $1 / 2$ of suppository $(20 \mathrm{mg} / \mathrm{ml}$ of clotrimazole), the final investigated concentration $1 / 1024$ suppositories $(0.04 \mathrm{mg} / \mathrm{ml}$ clotrimazole $)$. The content of clotrimazole in one suppository (in the samples of sample No. 1 to 7 with a total weight of 4.0 grams) was $400 \mathrm{mg}$. Based on the above, the concentration range of clotrimazole in experimental tubes with the specified preparation for Candida albicans was in the range from $20.00-0.04 \mathrm{mg} / \mathrm{ml}$.

The range of the test concentrations of the antimycotic ingredient of the comparator product ranged from $5 \mathrm{mg} / \mathrm{ml} \mathrm{miconazole} \mathrm{to} 0.01 \mathrm{mg} / \mathrm{ml}$ of miconazole.

All experiments were carried out in triple repetitions according to the requirements of pre-clinical studies in vitro. The results were recorded visually, by comparing the intensity of growth of test cultures on Petri dishes with sampled drug with growth culture in control.

\section{Results and their discussion.}

On the basis of previous studies conducted at the Department of Pharmaceutical Technology and Biopharmacy of the National Medical Academy of Postgraduate Education named after P.L. Shupik under the direction of Professor L. L. Davtyan, a potential medicinal product for intravaginal administration containing three active substances was developed: metronidazole , clotrimazole and ibuprofen. The chosen dosage form should provide immediate action at the center of the inflammatory process, which will potentially contribute to a significant reduction in the frequency of undesirable side effects.

Results of the study of antimycotic activity of model specimens number 4 containing one active ingredient, clotrimazole, are given in table. 2 , indicate the presence of antimycotic activity in this sample in relation to both the reference strain Candida albicans ATCC 10231 and the clinical strain Candida albicans.

Sample No. 4 (base + clotrimazole) was found to have a distinct fungistatic and fungicidal activity against the studied fungi of the Candida genus, due to the inhibition of the ergosterol biosynthesis which regulates the permeability of the cell wall of the microorganisms. The inhibition of the Candida albicans strain ATCC 10231 was observed at the dilution of the drug to $1 / 128$ suppositories, the MIC (minimum inhibitory concentration) was $0.315 \mathrm{mg} / \mathrm{ml}$ clotrimazole, for the clinical strain Candida albicans dilution was $1 / 32$ (MIC $-1.25 \mathrm{mg} / \mathrm{ml}$ ). Comparing the activity of sample No. 4 to reference and clinical isolates, the MIC was higher for the clinical strain, due to the formation of resistance of the microorganisms, which developed a certain set of mechanisms of resistance to the action of antifungal drugs.

Subsequent experimental studies were conducted to confirm the absence of a negative pharmacological interaction in the two-component Sample No. 6 (clotri- 
mazole + ibuprofen) and the three-component Sample No.7 (clotrimazole + metronidazole + ibuprofen), which could subsequently affect the antimycotic activity of the drug. Listed in tab. 3, 4 results of the analysis of in vitro antifungal activity of samples No. 6 and 7 containing clotrimazole in a concentration from 20 to $0.04 \mathrm{mg} / \mathrm{ml}$ in relation to pathogenic test strains: Candida albicans ATCC 10231, Candida albicans (clin. strain) (Table 3) demonstrated the presence of comparable antimycotic activity with sample No. 4 (clotrimazole + base), suggesting the absence of pharmacodynamic interaction (synergism or antagonism) between clotrimazole, metronidazole and ibuprofen.

Thus, it was found that Samples No. 6 and No. 7 had a pronounced antimycotic activity in the Candida species of the studied fungi only due to the presence of clotrimazole in the APIs with fungicidal and fungistatic activity. Inhibition of the Candida albicans strain ATCC 10231 was observed at dilution of the preparation to $1 / 128$ suppository (MIC clotrimazole $-0.315 \mathrm{mg} / \mathrm{ml}$ ), for the clinical strain Candida albicans dilution was 1/32 (MIC clotrimazole $-1.25 \mathrm{mg} / \mathrm{ml}$ ). The maximum antimycotic effect against Candida albicans ATCC 10231 was achieved at dilution to $1 / 16$ suppository (based on the concentration of clotrimazole in the sample $2.5 \mathrm{mg} / \mathrm{ml}$ ), and for the clinical strain Candida albicans $1 / 2$ suppository (in terms of concentration of clotrimazole in the sample $-10 \mathrm{mg} / \mathrm{ml}$ ).

Confirmation of absence of antifungal activity in vitro of samples No. 1, No. 2, No. 3 and No. 5, which do not contain APIs containing an expressive antifungal activity, for pathogenic test strains: Candida albicans ATCC 10231, Candida albicans (clinical strain) shown in Table 5.

The results of the analysis of the antifungal activity of the comparison drug "NEO-PENOTRAN®" containing miconazole in a concentration from 5 to $0.01 \mathrm{mg} / \mathrm{ml}$ in vitro for pathogenic test strains: Candida albicans ATCC 10231, Candida albicans (clinical strain) are given in Table 6.

Table 2

Antimycotic activity of Sample No. 4 in relation to Candida albicans (ATCC 10231 and clinical strain)

\begin{tabular}{|c|c|c|c|c|c|c|c|}
\hline \multirow[t]{2}{*}{$\begin{array}{l}\text { No. } \\
\text { study }\end{array}$} & \multirow{2}{*}{$\begin{array}{l}\text { Concentration of the active ingredient - clotrima- } \\
\text { zole in } \mathrm{mg} / \mathrm{ml} \text { (dilution of the preparation supp/10 } \\
\mathrm{ml} \text { of the medium) }\end{array}$} & \multicolumn{3}{|c|}{$\begin{array}{l}\text { Candida albicans ATCC } \\
10231\end{array}$} & \multicolumn{3}{|c|}{$\begin{array}{l}\text { Candida albicans clin. } \\
\text { strain }\end{array}$} \\
\hline & & $\begin{array}{c}\mathrm{I} \\
\text { repeat }\end{array}$ & $\begin{array}{c}\text { II } \\
\text { repeat }\end{array}$ & $\begin{array}{c}\text { III } \\
\text { repeat }\end{array}$ & $\begin{array}{c}\mathrm{I} \\
\text { repeat }\end{array}$ & $\begin{array}{c}\mathrm{II} \\
\text { repeat }\end{array}$ & $\begin{array}{c}\text { III } \\
\text { repeat }\end{array}$ \\
\hline 1. & $20(1 / 2)$ & --- & --- & --- & --- & --- & --- \\
\hline 2. & $10(1 / 4)$ & -- & $-\cdots$ & --- & --+ & --+ & --+ \\
\hline 3. & $5(1 / 8)$ & -- & -- & -- & --+ & --+ & --+ \\
\hline 4. & $2.5(1 / 16)$ & --- & $-\cdots$ & --- & -++ & --+ & --+ \\
\hline 5. & $1.25(1 / 32)$ & --+ & --- & --- & -++ & -++ & -++ \\
\hline 6. & $0.63(1 / 64)$ & --+ & --+ & --+ & +++ & +++ & +++ \\
\hline 7. & $0.315(1 / 128)$ & -++ & -++ & -++ & +++ & +++ & +++ \\
\hline 8. & $0.16(1 / 256)$ & +++ & +++ & +++ & +++ & +++ & +++ \\
\hline 9. & $0.08(1 / 512)$ & +++ & +++ & +++ & +++ & +++ & +++ \\
\hline 10. & $0.04(1 / 1024)$ & +++ & +++ & +++ & +++ & +++ & +++ \\
\hline 11. & Cultural control & +++ & +++ & +++ & +++ & +++ & +++ \\
\hline
\end{tabular}

Notes: $+++-100 \%$ intensive growth of microorganisms, similar to culture growth without preparation; - ++ - growth of microorganisms by $30 \%$ suppressed relative to the growth of culture without the preparation; - - + - growth of microorganisms by $60 \%$ suppressed relative to the growth of culture without the preparation; - - - complete inhibition of growth of microorganisms

Table 3

Antimycotic activity of Sample No. 6 in relation to Candida albicans (ATCC 10231 and clinical strain)

\begin{tabular}{|c|c|c|c|c|c|c|c|}
\hline \multirow[t]{2}{*}{$\begin{array}{l}\text { No. } \\
\text { study }\end{array}$} & \multirow{2}{*}{$\begin{array}{c}\text { Dilution of the preparation supp/10 } \mathrm{ml} \text { of the } \\
\text { medium ( } \mathrm{mg} / \mathrm{ml} \text { of the active ingredient - } \\
\text { clotrimazole) }\end{array}$} & \multicolumn{3}{|c|}{$\begin{array}{c}\text { Candida albicans ATCC } \\
10231\end{array}$} & \multicolumn{3}{|c|}{$\begin{array}{l}\text { Candida albicans clin. } \\
\text { strain }\end{array}$} \\
\hline & & I repeat & $\begin{array}{c}\text { II } \\
\text { repeat }\end{array}$ & $\begin{array}{c}\text { III } \\
\text { repeat }\end{array}$ & $\begin{array}{c}\mathrm{I} \\
\text { repeat }\end{array}$ & $\begin{array}{c}\text { II } \\
\text { repeat }\end{array}$ & $\begin{array}{c}\text { III } \\
\text { repeat }\end{array}$ \\
\hline 1. & $1 / 2(20)$ & --- & $-\ldots$ & $-\ldots$ & $-\ldots$ & --- & --- \\
\hline 2. & $1 / 4(10)$ & --- & --- & $-\cdots$ & --+ & --+ & --+ \\
\hline 3. & $1 / 8(5)$ & $-\ldots$ & $-\ldots$ & $-\ldots$ & --+ & --+ & --+ \\
\hline 4. & $1 / 16(2.5)$ & --- & --- & --- & -++ & --+ & --+ \\
\hline 5. & $1 / 32(1.25)$ & --- & -- & -- & -++ & -++ & -++ \\
\hline 6. & $1 / 64(0.63)$ & --+ & --+ & --+ & +++ & +++ & +++ \\
\hline 7. & $1 / 128(0.315)$ & -++ & -++ & -++ & +++ & +++ & +++ \\
\hline 8. & $1 / 256(0.16)$ & +++ & +++ & +++ & +++ & +++ & +++ \\
\hline 9. & $1 / 512(0.08)$ & +++ & +++ & +++ & +++ & +++ & +++ \\
\hline 10. & $1 / 1024(0.04)$ & +++ & +++ & +++ & +++ & +++ & +++ \\
\hline 11. & Cultural control & +++ & +++ & +++ & +++ & +++ & +++ \\
\hline
\end{tabular}


Table 4

Antimycotic activity of Sample No. 7 in relation to Candida albicans (ATCC 10231 and clinical strain)

\begin{tabular}{|c|c|c|c|c|c|c|c|}
\hline \multirow[t]{2}{*}{$\begin{array}{l}\text { No. } \\
\text { study }\end{array}$} & \multirow{2}{*}{$\begin{array}{c}\text { Dilution of the preparation supp/10 } \mathrm{ml} \text { of the } \\
\text { medium ( } \mathrm{mg} / \mathrm{ml} \text { of the active ingredient - } \\
\text { clotrimazole) }\end{array}$} & \multicolumn{3}{|c|}{$\begin{array}{l}\text { Candida albicans ATCC } \\
10231\end{array}$} & \multicolumn{3}{|c|}{$\begin{array}{l}\text { Candida albicans clin. } \\
\text { strain }\end{array}$} \\
\hline & & I repeat & $\begin{array}{c}\text { II } \\
\text { repeat }\end{array}$ & $\begin{array}{c}\text { III } \\
\text { repeat }\end{array}$ & $\begin{array}{c}\mathrm{I} \\
\text { repeat }\end{array}$ & $\begin{array}{l}\text { II } \\
\text { repeat }\end{array}$ & $\begin{array}{c}\text { III } \\
\text { repeat }\end{array}$ \\
\hline 1. & $1 / 2(20)$ & $-\cdots$ & --- & --- & --- & $-\cdots$ & --- \\
\hline 2. & $1 / 4(10)$ & --- & --- & $-\cdots$ & --+ & --+ & --+ \\
\hline 3. & $1 / 8(5)$ & --- & --- & --- & --+ & --+ & --+ \\
\hline 4. & $1 / 16(2.5)$ & $-\cdots$ & --- & $-\cdots$ & -++ & --+ & --+ \\
\hline 5. & $1 / 32(1.25)$ & --- & $-\cdots$ & --- & -++ & -++ & -++ \\
\hline 6. & $1 / 64(0.63)$ & --+ & --+ & --+ & +++ & +++ & +++ \\
\hline 7. & $1 / 128(0.315)$ & -++ & -++ & -++ & +++ & +++ & +++ \\
\hline 8. & $1 / 256(0.16)$ & +++ & +++ & +++ & +++ & +++ & +++ \\
\hline 9. & $1 / 512(0.08)$ & +++ & +++ & +++ & +++ & +++ & +++ \\
\hline 10. & $1 / 1024(0.04)$ & +++ & +++ & +++ & +++ & +++ & +++ \\
\hline 11. & Cultural control & +++ & +++ & +++ & +++ & +++ & +++ \\
\hline
\end{tabular}

Table 5

Antimycotic activity of Samples No. 1, No. 2, No. 3, and No. 5 in relation to both Candida albicans (ATCC 10231 and clinical strain)

\begin{tabular}{|c|c|c|c|c|c|c|c|c|c|}
\hline \multirow{2}{*}{$\begin{array}{l}\text { No. } \\
\text { study }\end{array}$} & \multirow{2}{*}{$\begin{array}{l}\text { Dilution of the } \\
\text { preparation } \\
\text { supp/10 ml of the } \\
\text { medium }\end{array}$} & \multicolumn{4}{|c|}{ Candida albicans ATCC 10231} & \multicolumn{4}{|c|}{ Candida albicans clin. strain } \\
\hline & & $\begin{array}{c}\text { Sample } \\
\text { No. } 1\end{array}$ & $\begin{array}{c}\text { Sample } \\
\text { No. } 2\end{array}$ & $\begin{array}{c}\text { Sample } \\
\text { No. } 3\end{array}$ & $\begin{array}{c}\text { Sample } \\
\text { No. } 5\end{array}$ & $\begin{array}{c}\text { Sample } \\
\text { No. } 1\end{array}$ & $\begin{array}{c}\text { Sample } \\
\text { No. } 2\end{array}$ & $\begin{array}{c}\text { Sample } \\
\text { No. } 3\end{array}$ & $\begin{array}{c}\text { Sample } \\
\text { No.5 }\end{array}$ \\
\hline 1. & $1 / 2$ & +++ & +++ & +++ & +++ & +++ & +++ & +++ & +++ \\
\hline 2. & $1 / 4$ & +++ & +++ & +++ & +++ & +++ & +++ & +++ & +++ \\
\hline 3. & $1 / 8$ & & +++ & +++ & +++ & & +++ & +++ & +++ \\
\hline 4. & $1 / 16$ & & +++ & +++ & +++ & & +++ & +++ & +++ \\
\hline 5. & Cultural control & +++ & +++ & +++ & +++ & +++ & +++ & +++ & +++ \\
\hline
\end{tabular}

Table 6 Research of the antimycotic activity of the reference preparation "NEO-PENOTRAN®" in relation to Candida albicans (ATCC 10231 and clinical strain)

\begin{tabular}{|c|c|c|c|c|c|c|c|}
\hline \multirow[t]{2}{*}{$\begin{array}{l}\text { No. } \\
\text { study }\end{array}$} & \multirow{2}{*}{$\begin{array}{l}\text { Dilution of the preparation supp/10 } \mathrm{ml} \text { of the } \\
\text { medium }(\mathrm{mg} / \mathrm{ml} \text { of the active ingredient - } \\
\text { miconazole) }\end{array}$} & \multicolumn{3}{|c|}{$\begin{array}{c}\text { Candida albicans ATCC } \\
10231 \\
\end{array}$} & \multicolumn{3}{|c|}{$\begin{array}{l}\text { Candida albicans clin. } \\
\text { strain }\end{array}$} \\
\hline & & $\begin{array}{l}\text { I re- } \\
\text { peat }\end{array}$ & $\begin{array}{c}\text { II } \\
\text { repeat }\end{array}$ & $\begin{array}{c}\text { III } \\
\text { repeat }\end{array}$ & $\begin{array}{c}\mathrm{I} \\
\text { repeat }\end{array}$ & $\begin{array}{c}\text { II } \\
\text { repeat }\end{array}$ & $\begin{array}{c}\text { III } \\
\text { repeat }\end{array}$ \\
\hline 1. & $1 / 2(5)$ & -- & $-\cdots$ & -- & --+ & --+ & --+ \\
\hline 2. & $1 / 4(2.5)$ & --- & -- & -- & --+ & --+ & --+ \\
\hline 3. & $1 / 8(1.25)$ & --- & --- & --- & --+ & --+ & --+ \\
\hline 4. & $1 / 16(0.63)$ & --- & -- & --- & -++ & -++ & -++ \\
\hline 5. & $1 / 32(0.315)$ & --- & --- & --- & -++ & -++ & -++ \\
\hline 6. & $1 / 64(0.16)$ & --- & --- & --- & +++ & +++ & +++ \\
\hline 7. & $1 / 128(0.08)$ & --- & --- & --- & +++ & +++ & +++ \\
\hline 8. & $1 / 256(0.04)$ & -++ & -++ & -++ & +++ & +++ & +++ \\
\hline 9. & $1 / 512(0.02)$ & +++ & +++ & +++ & +++ & +++ & +++ \\
\hline 10. & $1 / 1024(0.01)$ & +++ & +++ & +++ & +++ & +++ & +++ \\
\hline 11. & Cultural control & +++ & +++ & +++ & +++ & +++ & +++ \\
\hline
\end{tabular}

The conducted studies have established (table 6) that the reference preparation "NEO-PENOTRAN®" with active ingredient miconazole has been shown to have a pronounced antimycotic activity against Candida albicans (ATCC 10231). A moderate antifungal effect is recorded at a concentration of $0.04 \mathrm{mg} / \mathrm{ml}$ of miconazole, corresponding to $1 / 256$ suppositories diluted in $10 \mathrm{ml}$ of medi- um. Less distinctive activity is shown by this sample in relation to the clinical strain Candida albicans. The antifungal effect is recorded at a concentration of $0.315 \mathrm{mg} / \mathrm{ml}$ of miconazole, which is 8 times higher than the MIC of miconazole relative to the museum strain (Fig. 1), which can be explained by the presence of a large number of resistant microorganisms resistant to miconazole. 


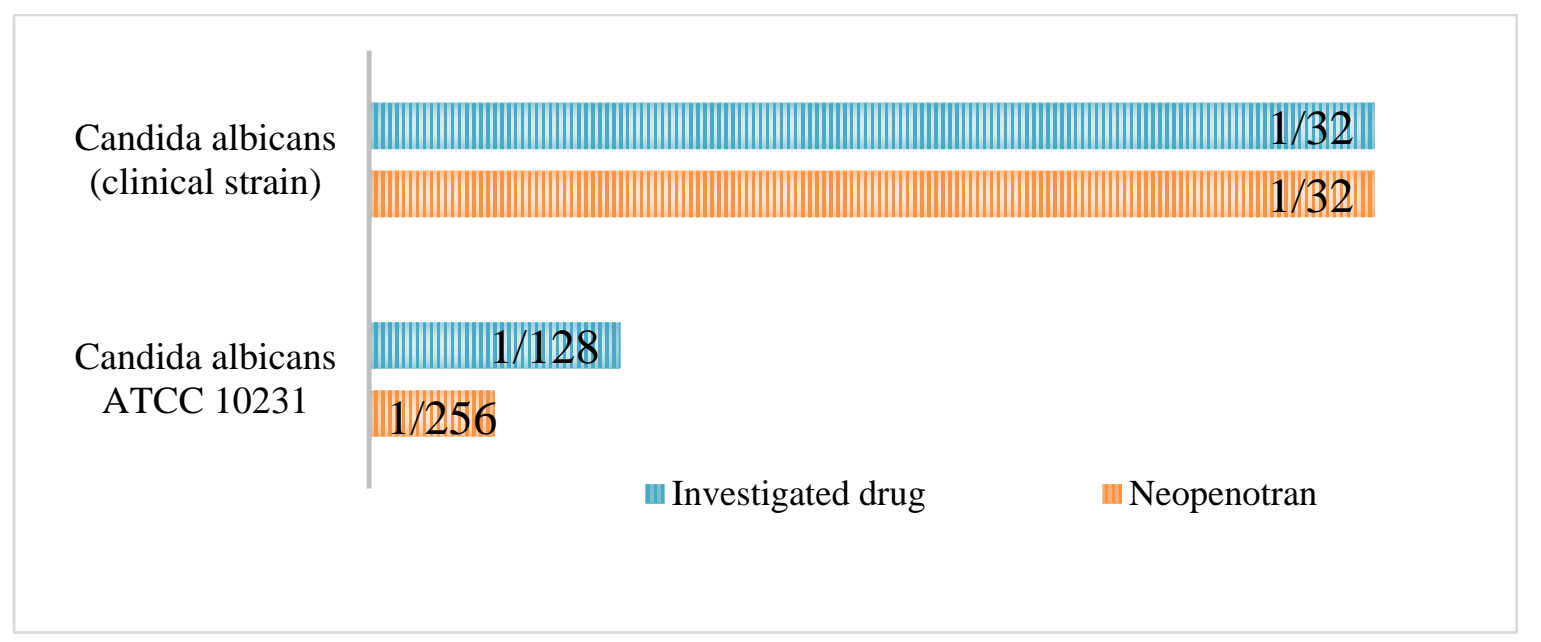

Fig. 1. Result of comparison of antimicrobial activity

The above results showed that the antimycotic activity of the study drug is not inferior to the activity of the selected reference preparation, and in relation to Candida albicans (clinical strain) is more pronounced, which is explained by the resistance of the strains to many antimycotic drugs with intravaginal administration.

However, the activity was lower in relation to Candida albicans ATCC 10231, which can be justified by different MICs of clotrimazole and miconazole, as well as different concentrations of APIs in suppositories.

7. Conclusions from the conducted research and prospects for further development of this field

1. The results of the studies indicate that there is a clear in vitro antimycotic effect of the new potential combined drug relative to pathogenic test strains: Candida albi- cans ATCC 10231, Candida albicans (clinical isolate).

2. A comparative study of the antimycotic activity of the experimental samples of the new combined drug and the referent drug showed an antimycotic effect in the investigated concentrations.

3. It has been found that the MIC of the test drug in vitro with regard to pathogenic test strains: Candida albicans ATCC 10231, Candida albicans (clinical isolate) is $0.315 \mathrm{mg} / \mathrm{ml}$ and $1.25 \mathrm{mg} / \mathrm{ml}$ clotrimazole, respectively.

4. The conducted microbiological study of various combinations and concentrations of the combined preparation allowed to exclude the presence of negative interaction between the components of the experimental sample and to allocate the most promising and effective sample for further experimental studies of combinations of antimycotics for intravaginal use.

\section{References}

1. Prilepskaya V. N. Genital candidiasis. Modern approaches to treatment // Obstetrics and gynecology. 1996. Issue 6. P. 28-29.

2. Kubas' V. G., Chayka N. A. Candidiasis. Saint Petersburg: Sotis, 2010. 40 p.

3. Pavlenko E. Yu., Ziyadinov M. S. The place of candidiasis in infectious pathology at the present stage // Crimean Journal of Experimental and Clinical Medicine. 2011. Vol. 1, Issue 2. P. 63-66.

4. Identification of Candida albicans isolated from Recurrent Vulvovaginal Candidiasis (RVVC) patients by PCR-RFLP method and its drug sensitivity to Zataria multiflora extract / Farasat A., Sadraeian M., Mohkam M., Akbari Rad S. // European Journal of Experimental Biology. 2012. Vol. 6, Issue 1. P. 58-61.

5. Sergeev A. Yu., Sergeev Yu. V. Candidiasis: Nature of infection, mechanisms of aggression and protection, laboratory diagnostics, clinic and treatment. Moscow: Triada-X, 2007. 472 p.

6. Evans E. Diagnostic laboratory techniques in vaginal candidosis // Journal of clinical microbiology. 2009. Vol. 47, Issue 12. P. 3821-3825.

7. LaFleur M. D., Qi Q., Lewis K. Patients with Long-Term Oral Carriage Harbor High-Persister Mutants of Candida albicans // Antimicrobial Agents and Chemotherapy. 2009. Vol. 54, Issue 1. P. 39-44. doi: 10.1128/aac.00860-09

8. A guide to preclinical drug research. Part 1/ A. N. Mironov (Ed.). Moscow: FGBU "NTSESMP", 2012. 944 p.

9. Stefanov A. V. Preclinical research of medicines. Kyiv: Avicenna, 2002. 320 p.

10. Golovkin V. A., Golovkin A. V., Golovkin V. V. Medicines for external therapy of inflammation of the urino-genital organs. Zaporozhye: ZMGU, 2003. 152 p.

Дата надходження рукопису 23.01.2018

Nizhenkovska Iryna, MD, Professor, Department of Pharmaceutical, Biological and Toxicological Chemistry, Bogomolets National Medical University, T. Shevchenko blvd., 13, Kyiv, Ukraine, 01601

E-mail: dekan-farm@ukr.net

Zinchenko Liudmyla, Assistant, Department of Pharmaceutical, Biological and Toxicological Chemistry, Bogomolets National Medical University, T. Shevchenko blvd., 13, Kyiv, Ukraine, 01601

E-mail: lucy.on04@gmail.com 